\title{
Taking Lessons from the Prophet in Times of War
}

\author{
Muhammadan Images during the Afghan Resistance (ca. 1978-92)
}

\author{
Jan-Peter Hartung
}

On 26 April 1978, the Leninist Khalq faction of the People's Democratic Party of Afghanistan (PDPA), led by former journalist Nūr Muhammad Tarakī (assassinated 1358sh/1979), seized power in a coup against the government of Muhammad Dāvūd Khān (assassinated 1357SH/1978), euphemistically called the "Śawr Revolution", and established the Democratic Republic of Afghanistan. ${ }^{1}$ With this, the more than a decade-long tug-of-war between antireligious leftists and emphatically religious forces in the country had reached a first culmination point. Almost instantly, the PDPA forces started to quell any potential resistance to their regime with brute force, culminating in the massacre of over a thousand villagers in Keṛālah in the north-eastern province of Kunar nearly exactly a year after the coup. The armed resistance to the PDPA regime, which emerged in response, ${ }^{2}$ soon evolved into a complex mesh of traditional ad hoc militias in rural Pashtun communities (lax̌karūnah; sing. lax̌kar), well-organised Islamist organisations of urban ${ }^{3}$ provenance, and armed outfits with social as well as ideological ties into both of the former. Moreover, this mesh also became almost instantly - although to substantially variant degrees - a pawn in the geopolitical manoeuvrings of numerous governments in the Age of the Cold War, which became even more severe after the Soviet military intervention in the country on Christmas Eve 1979. This invasion, in turn, resulted in the installation of a president more subservient to the interests of the CPSU leadership, as well as a continuous presence of Soviet armed forces in Afghanistan for an entire decade.

1 On the history of the PDPA, see Arnold, Afghanistan's Two-Party Communism.

2 See Saharī, Jihād dar Kunar'hā, $1-4$.

3 The underlying concept of "urbanity" here follows Gramsci, Quaderni del carcere, 3:2036, who defined it by ascribing to its modern-type inhabitants "across all social groups an urban ideological unity against the countryside, a unity which even the most modern nuclei in terms of civil function do not escape.... There is disgust and disdain for the 'villager', an implicit front against the demands of the countryside" (trans. J. A. Buttigieg).

(C) JAN-PETER HARTUNG, 2022 | DOI:10.1163/9789004466753_018

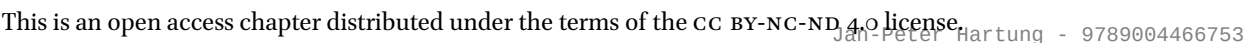


The resistance which these events triggered was immediately presented as a jiha $\bar{d}{ }^{4}$ thus casting it into an Islamic web of meaning that appealed to the conservative rural religiosity as well as to ideological precepts in the Islamist worldview, and could therefore guarantee a substantial mobilisation of male Afghans of diverse ethnic and socio-economic background. ${ }^{5}$ Unsurprisingly, discussions on the nature of jihād and the legal conditions for it figure prominently in the many periodic publications issued by the various carriers of the Resistance in a wide range of languages. ${ }^{6}$ While, perhaps for pragmatic reasons, there appears little disagreement in this matter, this is not so the case in the surprisingly sparse references to the Prophet Muhammad during that period. I therefore propose that a closer look at these various references will provide insight into the diverse ideological underpinnings of the various factions involved, and allows to finally class them roughly into two major camps: "Islamists", on the one hand, and what I will call "Frontier Deobandīs", on the other. Both factions are, of course, ideal-typical:" in reality, they overlapped more often than not, making a clear classification of any given militia challenging. Yet, I claim that my ideal-typical categories still carry some currency, as they reflect also distinct origins, social embeddedness, and frames of reference, ultimately including images of the Prophet.

In the following, I shall first map the various groups involved in the Afghan Resistance, already presenting them along the divide into "Islamists" and "Frontier Deobandīs". Next, the respective images on the Prophet Muhammad will be fleshed out, to be followed by an attempt to explain the differences between them in a kind of longue durée perspective. I have set the time frame

4 For example, Jalāl al-Dīn Ḥaqqānī, one of the protagonists in this chapter, was reported by his followers to have declared jihād already in response to Dāvūd Khān's own coup d'état in April 1973: see Khān, "Pah Afghānistān ke də jihād də lumṛanī 'amaliyāt", 19. In this regard, we need to bear in mind the by and large uncritically supportive attitude of Pashtun borderland tribes for the Barakzay monarchy (1826-1973), vis-à-vis competing political forces. See, for example, Khan, "The Pashtoon Resistance", 67-69.

5 This is based on my own review of almost 2,ooo obituaries for (exclusively male) resistance fighters from between 1980 and 1992, published in various periodicals during the Resistance by most of those militias that enjoyed substantial logistic and financial support from the governments of the USA, Pakistan, Iran, and Saudi Arabia.

6 See Fuchs, "Glossy Global Leadership".

7 While it should go without saying that such categories are necessarily bound to fail an identical representation of complex and contingent empirical entities, the oftentimes rather lax employment of categories such as "Islamist", which leads to widespread erroneous assumptions that they represent realities in a positivist fashion, suggests otherwise. By emphatically stressing the ideality of my descriptive categories, I wish to explicitly stress that my explanatory approach is a rather typecasting one, which necessarily confines the extent of my own analysis. 
1978-92 deliberately, as after the successful overthrowing of the regime of the Hizb-i Vațan, successor to the PDPA, by 1992 the impact of views and argument developed in militant Islamic circles in the MENA region would become more discernible in the wider Hindukush region, thanks to an ever-growing contingent of especially Arab militant exiles to the conveniently hard-tocontrol region.

\subsection{Mapping the Afghan Resistance}

For many people in predominantly rural Afghanistan the PDPA coup constituted only the culmination of a process of gentrification of the entire country that was conducted from Kabul. This process can be traced back to the reign of King Amānallāh of the Barakzī tribe within the Durrānī confederation in the early twentieth century, during which the monarch stipulated a programme of modernisation that, after all, remained confined to the larger cities only. ${ }^{8}$ The establishment of the - once again predominantly urban - PDPA regime and the subsequent Soviet invasion in December 1979, finally, offered a legitimate reason for concerted armed resistance.

Those who took up arms in opposition were of very diverse background and driven by variant motivations. Still, at least three clusters of actors can be ideal-typically established which, on the ground, interacted more often than not and begot countless hybrid forms both in terms of organisation as well as underlying inclinations. First are traditionally conservative rural communities, for a long time detached from the various agendas of whoever was in charge in Kabul. The PDPA strategy to develop these regions, many of which in the dominantly tribal Pashtun regions along the foothills of the Hindukush, was to mock the perceived backwardness of its respective population and to see through anti-religious and counter-traditional measures by force of arms. The religiosity in these regions was strongly shaped by forms of subaltern piety, ${ }^{9}$ which

8 See, for example, Askar, "The Will Not to Count", where he discusses the controversial topdown introduction of administrative core measures during Amānallāh's reign, such as the population census, the allocation of street names and house numbers, and the related introduction of central services such as the provision of electrical energy and water.

9 I am certainly acknowledging the heavy baggage that this term comes with, from the "classic subalterne" in Gramsci's Quaderni del carcere, via the so-called Subaltern Studies Group of the 1980s and 1990s, which includes also Gayatri Spivak's seminal, yet controversial, essay "Can the Subaltern Speak?" (1988). Still, this term has been deliberately selected as a purely analytical category against the less flexible concept of "(socio-economic) class" to grasp the lower strata of Pashtun society both in the rural as well as urban context. I understood 
also included prominently pious visitations of the graves of locally acknowledged saints as well as the belief in the miraculous powers of amulets; ${ }^{10}$ their social organisation strongly gender segregated, yet idealised as acephalous. ${ }^{11}$ Religious authority pivoted primarily on the authority of a Sufi shaykh and his local socio-religious infrastructure, here first and foremost basic education (tarbiyat) and feeding the poor (langar); ${ }^{12}$ their importance for the sociopolitical, however, has been well recognised by the local and imperial powerholders who have subsequently attempted to tie those Sufi shuyūkh closer to their own circles, furthering their own respective interested. ${ }^{13}$ Yet, whatever their proclivities towards or against worldly power, it were quite often these local religious dignitaries who would translate distinct political agendas - either those of their political patrons or their own - into rallying innumerable and oftentimes only locally active tribal militias (lax̌karūnah) whose objective was

"subaltern" here as a relational one to that of "elite" and entirely context bound: who might be "subaltern" in one constellation can well be "elite" in another. Moreover, and much in line with the current state of discussion of this term (see e.g. Ludden, "A Brief History of Subalternity", esp. 19ff; Green, "Rethinking the Subaltern"), subalternity does by no means deny voice or agency - in fact, as stated early on by Chakrabarty, "Invitation to a Dialogue", 376 , it reflects "the composite culture of resistance to and acceptance of domination and hierarchy". This definition appears useful, as it can also account for the fact that subaltern actors buy well into the same coercive framework as elites, and are not immune from elitist tendencies as well.

10 For such religious practices, see Marsden, Living Islam, esp. 157-92.

11 The rather romantic image of Pashtun society as an essentially acephalous one owes much to the otherwise pioneering work of Barth, Political Leadership among Swat Pathans, 12 and 104-27, on which the author revised his position somewhat in Features of Person and Society in Swat, 121-81. For the issue of all-comprehensive gender segregation in Pashtun rural communities, which already disenchants the myth of acephalousness, see Grima, Secrets from the Field.

12 See Wieland-Karimi, Islamische Mystik in Afghanistan, 147-51 and esp. 161; Caron, "Sufism and Liberation", $138 \mathrm{ff}$. and 144.

13 This insight requires us to employ a modified image of the Sufi shaykh and his sociopolitical integrative potential: at least in the regional context under review, their close- or aloofness from political power led to opposing socio-economic constituencies. Indeed, harsh criticism against shuyükh who have compliably submitted to the pull of political power gave therefore rise to severe criticism by those remaining exclusively dependent on their spiritual capital. This, in fact, had been the case already when Ahmmad Shāh Durrānī (r. 1747-72) tried to tie Pashtun shuyükh of various provenance to his court in Kandahar; a more contemporary case in point is that of Sayyid Amīn al-Ḥasanāt (d. 1379/196o), the Pīr Șāhịib of Mānkī Sharīf some twenty miles east of Nowshera, who would even act in the Pashtun communities as an agent of the first Pakistani government and its military apparatus. See Kākākhel, Pīr șāhib-i Mānkī-yi sharīf Sayyid Aminn al-Hasanāt, 99-106. 
first and foremost to regain the authority over their communal affairs, including religious ones, from the grips of the imperial central government. ${ }^{14}$

The other two ideal-typical clusters are, in fact, those who are in focus of the following exposition, with at least partially similar dismissive views of local beliefs and practices especially in the rural communities as the PDPA and its various Marxist, Leninist, and Maoist ancillaries. The first one, in fact, originated in the very same urban and educational environment as the PDPA, and responded to similar societal problems in an - ostensibly - diametrically opposed fashion: the "Islamists". In the late 195os, a first Islamist circle began to form at Kabul University around Ghulām Muḥammad Niyāzī (pressumably killed 1398/1978), then professor at the Sharīa Faculty, which included later militia commanders Burhān al-Dīn Rabbānī (assassinated 1432/2011), 'Abd al-Rabb Rasūl Sayyāf (b. 1364/1945) and also, though more loosely, students of engineering Gulbuddīn Ḥikmatyār (b. 1366/1947) and Aḥmad Shāh Mas'ūd (assassinated 1422/2001). Niyāzī had embraced Islamist thought during a twoyear study trip to Cairo, where he got acquainted with the Jamā'at al-Ikhwān al-Muslimin (JIM) during a time of state persecution for the alleged assassination attempt on President Nasser in October $1954 \cdot{ }^{15}$ Only a few years later, his principal students Rabbānī and Sayyāf followed suit and earned master's degrees from al-Azhar in Islamic philosophy and 'ulüm al-hadìth, respectively. ${ }^{16}$ In the following years, especially Rabbānī and the circle of students that formed around him drew systematic inspiration from the thought of early Egyptian Muslim Brethren, ${ }^{17}$ while Niyāzī laid the foundations of an Islamist

14 A prominent representative of this cluster within the Afghan Resistance was Malik Muhammad Zarīn (assassinated 1432/2011), a landowner of the Mashvānī tribe of Binshāhī in Lower Dīr on the Pakistani side of the border with Afghanistan, with property on either side of the borderline. Zarin entered into coalitions with about everyone deemed useful for achieving his locally and ethnically confined goals. Personal information by a member of a family of masharān from Upper Dīr, Bārah Galī (Pakistan), 10 August 2017.

15 See "Yādī az ustad Ghulām Muḥammad Niyāzī mu’assis-i Nahẓat-i Islāmī dar Afghānistān", Mīsāa-i Khūn 1/2 (1359sh/1401H), 8ff.; "Yādī az ustad pohānid 'Niyāzī”,, Mīssāq-i Khūn 1/5 (1360sh/1401H), 13, and 1/6-7 (136osh / 1401H), 12ff.

16 See "Mukhtașar zindigīnāmah-i ustād Burhān al-Dīn Rabbānī - rahbar-i Jamciyyat-i Islāmī-yi Afghānistān", Mīsāa-i Khūn 1/2 (1359sh/1401H), 21ff., here 21; also 'Abd Rabbih, 'Abd Rabb al-Rasül Sayyāf, 24.

17 See, for example, Dr Sayyid Muhammad Mūsā Tavānā, "Junbish'hā-yi islāmī dar pīch va khamm-i tārīkh", Mīsāā-i Khūn 1/4 (1359SH/1401H), 11ff.; 1/5 (1359SH/14O1H), 9-12; 1/7

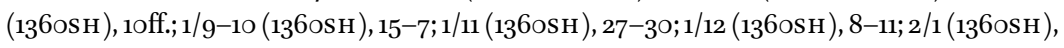
8ff.; 2/3 (136osh ), 17ff.; and 2/4 (136osh), 19-22; Engineer 'Abd al-Vadūd "Khālid": "Ikhvān al-Muslimīn dar masīr-i dacvat", Haqq Pāćūn 2/12-13 (1367sH), 54-56, 2/14-15 (13675H), 51-54, 2/18 (1368sh), 50-52; "Mașāḥibah-yi kih murshid-i 'āmm-i Jamciyyat-i Ikhvān al-Muslimīn pīrāmūn-i jihād-i Afghānistān șūrat giriftah ast", Haqq Pācūnn 2/8 (1367sH), 
jurisprudence in Afghanistan with his principle work Ma'äkhiz-i Duvvum-i Fiqh-i Islämī. ${ }^{18}$ This way, Islamist core concepts, such as prominently that of the "Islamic revolution" (inqilāb-i islāmì) and the "establishment of the government of divine justice" (iqāmah-yi ḩukūmat-i 'adl-i ilāhì), were introduced to the wider Islamic discourse in pre-communist Afghanistan, ${ }^{19}$ but pointed already to a high potential for conflict with the locally established and maintained forms of subaltern religiosity in a rural setting. To the Islamists, the armed resistance to an emphatically anti-religious and oppressive regime offered a golden opportunity to pursue their long-term goal, namely, the establishment of a normatively grounded Islamic polity, which would necessarily clash with the established forms of Muslim religiosity in rural communities throughout Afghanistan..$^{20}$ Yet, for the sake of argument, I shall confine my further exposition predominantly to Pashtun Islamist circles.

The third ideal-typically construed cluster of (Pashtun) actors in the Afghan Resistance, finally, originates largely in the same milieu as the locally active tribal militias, yet share, at least to an extent, the elitist attitudes of Islamist vis-à-vis local religious beliefs and practices: those who represent what I call "Frontier Deobandiyyat". This reformist current was carried into the "Pashtun borderland", ${ }^{21}$ and from there further into Afghanistan and Eastern Iran, ${ }^{22}$ by the anti-colonial agitation of Mahmuud al-Hasan, better known by his epithet "Shaykh al-Hind" (d. 1339/1920), and a circle of students, many of whom natives

6-8. All these and other references to the JIM in the periodicals of the Islamist organisations in the Afghan Resistance defy to an extent the assessment of Fuchs, "Glossy Global Leadership", 189, that the ideological reference of these organisations to the JIM was less substantial than generally assumed.

18 See Niyāzī, Ma’ākhizz-i duvvum-i fiqh-i islāmī, esp. 30-149. Hermeneutically significant, other than Islamist theorists like Abū l-Álā Mawdūdī, Niyāzī stressed the indispensable importance of the Prophetic sunna as enshrined in the six canonical collections of hadith. Mawdūdī, in turn, had argued that legal precepts can, and should ideally, be derived exclusively from the Qurānic revelation. See Hartung, A System of Life, 83-9o.

19 See, for example, Rabbānī, Irshād-i jihād, 126 (here in a speech delivered to his partisans in Peshawar in April 1983); Rabbānī, Āmūkhtānihāyī: this transcript of a lengthy speech was first published in 1360sH /1981-82, and was earlier serialised in the JIA-journal Miss $\underline{a} q-i$ Khün 1/11 (136оSн), 12-7; 1/9-10 (136oSH), 24-28; 2/1 (136oSH), 12-16; 2/2 (136оSH), 9-11; 2/3 (1360SH), 9-11.

20 The various Islamist organisations within the Afghan Resistance comprised all ethnic, linguistic, and denominational groups in Afghanistan. For a breakdown, see Olesen, Islam and Politics, $281-85$.

21 An attempt in theoretically sustaining this notion beyond the common angle of international relations is Hartung, "Of Pious Missions", 3-5.

22 For Afghanistan, see Olesen, Islam and Politics, 46 and 107ff.; for south-eastern Iran, see Dudoignon, The Baluch, Sunnism and the State in Iran, 3-5 and 149-70. 
of the Pashtun borderland with further-reaching connections to local religious authorities. ${ }^{23}$ They succeeded in casting a net of madāris over the region, its most significant one being the Dār al-Ulūm Haqqāniyyah in Akoṛah Khaṫak near Peshawar, established in 1947 by 'Abd al-Ḥaqq Akoravī (d. 1409/1988), a student of the Shaykh al-Hind's foremost disciple Husayn Ahmad Madanī (d. 1377/1957).. ${ }^{24}$ Two Pashtuns from Afghanistan who, in turn, had studied with 'Abd al-Haqq even before the official inauguration of the Dār al-'Ulūm would eventually emerge as leading representatives of Frontier Deobandiyyat during the armed resistance against the PDPA regime and its Soviet allies: Muhammad Yūnus Khāliṣ (d. 1427/2006) and Jalāl al-Dīn Ḥaqqānī (d. 1440/2018). ${ }^{25}$ Further spiritual nourishment was provided by Pashtun Deobandī scholars who set up shop in Karachi since the late 197os; ${ }^{26}$ go-between was Sayyid Shīr 'Alī Shāh Madanī (d. 1437/2015), one further fellow student of Khālis and Ḥaqqānī. ${ }^{27}$

Of all these actors, Khālis at least turns out difficult to pin down. ${ }^{28}$ True to the common image of a highly flexible and pragmatic borderland actor, he defies categorisation as either a clear-cut representative of Frontier Deobandiyyat or Islamism proper, but, in fact, manoeuvred constantly between both poles. Having himself studied in Cairo, it is quite likely that Khālis knew Niyāzī, who had returned from there only a little earlier. While in charge of a religious programme on Kabul Radio, Khāliṣ had his Dari translation of Sayyid Quṭb's seminal al-Adāla al-ijtimāìyya fì l-islām published, ${ }^{29}$ to be followed by

23 See Hartung, "The Praiseworthiness of Divine Beauty", 355-59; Hartung, "Of Pious Missions", 11-14.

24 See Akoravī, Fatāvā-yi ḥaqqāniyyah, 1:10off.; Ḥaqqānī, Savāniḥ-i shaykh al-ḥadīs Hažrat Mawlānā 'Abd al-Haqq, 43-58.

25 See 'Azīz Allāh, Də Mawlavī Khāliṣ žvand, fann aw and, ıff.; "al-Ḥājj Mawlavī Jalāl al-Dīn Ḥaqqānī lah (al-Nașịhah) sarah pah marakah ke: ćangah chih malgarī millatūnah də kufrī țāqatūno tar tāsīr lāndəy dī gadūn hīć bīrūnī qawt tah də hevād pah dākhilī chārūkəy", Manba al-Jihād [Pashto] 2/5 (1369sh/1411H), 36-42 and 52, here 41 .

26 Karachi had become a major destination for Afghan refugees after the PDPA coup d'état in April 1978; its dīn̄ madāris, predominantly of Deobandī provenance, serving as major sanctuaries for the economically (and also politically) disadvantaged arrivals from Afghanistan. See Gayer, Karachi, 163-204; on the systematic political discrimination of Afghan refugees by the Pakistani state authorities, see Alimia, "Performing the Afghanistan-Pakistan Border".

27 See "al-Sīra al-dhātiyya li-l-shaykh al-Duktūr Shīr 'Alī Shāh al-Madanī", in Madanī, Yād, 17-19, here 17 .

28 The same, in fact, applies to one more important leader in the Resistance, Muhammad Nabī Muhammadī (d. 1423/2002), leader of the Ḥarakat-i Inqilāb-i Islāmī. I had to leave him out of this discussion, because at the time of writing in early 2019 I was still lacking the relevant text material.

29 Published as Sayyid Quṭb: Islām va 'adālat-i ïtimā̄í, 2 vols (Kabul, Anjuman-i tarbiyyat va afkār, 1339sh). 
further translations from works of leading figures of the JIM, such as al-Din wa-l-hadāra al-insāniyya by Muhammad al-Bahī (d. 1402/1982). ${ }^{30}$ While the relationship between Khāliṣ and the Niyāzī circle in Kabul would remain only informal, from about 1968 Khālis would become more formally involved in a similar circle in Jalalabad. ${ }^{31}$ Yet, true to his origins in the socially conservative rural environments of the western Pashtun borderland, Khālis remained at least partly distinct from his Islamist compatriots in the cities.

\subsection{The Prophet as Strategist: The Primacy of This World}

For Islamically inspired actors, the PDPA regime since April 1978 and the subsequent Soviet invasion in December 1979 offered a legitimate reason to armed resistance. Yet, to the Islamists who grew out of the university campuses of the larger Afghan cities it also offered a chance to pursue their long-term goal, namely, the establishment of a normatively grounded Islamic polity. Consequently, references to the Islamic heritage, prominently including those to the Prophet Muhammad, were usually made with this objective in view.

Perhaps the bluntest reference in this regard was made in the autumn of 1988 in Shafaq, the magazine of the Hikmatyār-led Hizb-i Islāmī (ḤiI-Ḥ), in which the Prophet was presented as a military strategist only, from whom to learn would be similar than to study, let us say, Carl von Clausewitz (d. 1831). From the references to the punitive expeditions against the (Jewish) Banū Qurayża and the Banū Lahyān, the conquest of Mecca and the military campaign of the early Muslims against the Byzantines at Tabūk, ${ }^{32}$ author Muhammad Rahịm "Kanjar" distilled six tactical principles, which, because of their attribution to the Prophet, were ascribed authoritative status. Yet, the six principles are hardly exceptional: they revolve much around speed and surprise in attack, provided for by the choice of preferably difficult territory and moment of time for striking from an unexpected direction. Perhaps only two principles have wider implications: the first consists in the deliberate concealment of one's strength and determination, the second in the use of surprise means in military engagement.

30 Published as Muhammad al-Bahī: Dìn aw insānī tamaddun (Kabul, Dawlatī mațba'ah, 1351SH).

31 See 'Azīz Allāh, Do Mawlavī Khāliṣ žvand, fann aw and, 27-33; also Ṭalāyī, Khāliṣ Bābā, $33-36$.

32 See "Khanjar", Muḥammad Raḥimm: "Də Rasūl Allāh - șallā Allāh 'alayhi wa-sallam - jangī tāktīk", Shafaq 2nd series 3/3-4 (13675H), 33ff. All these events are well attested in the sìra and maghāzī literature: see, prominently, Ibn Hishām, al-Sìra al-nabawiyya, 2:233-54, 279-81, 389-426, and 515-31; Wāqidī, al-Maghāzī, 496-521, 535-37, 78o-871, and 985-1002. 
Especially the latter had been liberally employed by later militant Jihādī theorists who either developed their thought during their participation in the Afghan Resistance-turned-militancy from around 1987 onwards, or have turned out to be sources of inspiration for increasingly radical militants in the Pashtun borderland. Thus, for example, the Egyptian known, among various aliases, as Sayyid Imām al-Shariff (b. 1369/1950) highlighted in al-Umda fi i idād al-'udda li-l-jihād fì sabīl Allāh, written during his participation in the Afghan Resistance, the legal permissibility, even commendability, of using civilian non-combatants strategically as protective shields (tatarrus), ${ }^{33}$ a view that would be further refined by Abū Yahyā al-Lībī (killed 1433/2012) during his active time with factions of the Tahriik-i Ṭālibān-i Pākistān (тṬP) in North Waziristan. ${ }^{34}$ More disturbingly in line with the tactical precept to employ unknown means is a fatwa by Saudi Arabian scholar Nāșir b. Ḥamad al-Fahd (b. 1388/1968), which would become widely read in Pashtun militant circles, ${ }^{35}$ and in which he legally justified the employment of weapons of mass destruction by establishing an analogy to the Prophet's own practice. Muhammad himself was reported to have used innovative technology such as the catapult during the campaign against the people of Țầif, ${ }^{36}$ ordered the deliberate destruction of an enemy's means of living when having the date palm trees of the Jewish Banū Nadīr burned down in retaliation for their alleged breaking of the covenant of Medina, ${ }^{37}$ and had wells of the opposition poisoned and lethal animals, such as scorpions and snakes, employed in warfare. ${ }^{38}$

For other Pashtun Islamist representatives of the Afghan Resistance, meanwhile, such military strategic considerations appear to have been of lesser importance, and they would address another virulent issue through the prism

33 See Ibn 'Abd al-'Azīz, al-'Umda fí i'dād al-'udda, 3o, 33-35, 86ff., 3०3, 313, 328ff., 357ff., and 372ff. Sayyid Imām's predominant legal reference here is Ibn Qudāma's al-Mughnī. See also Fuchs, Proper Signposts for the Camp, 83-85; Nedza, "Takfir im militanten Salafismus", 92, 174, and 235 n.63.

34 Libī's infamous treatise on the subject, released after his escape from US captivity in December 2005, is titled al-Tatarrus fi l-jihād al-mu'assir. For an analysis of that text, see Brachman and Warius, "Abu Yahya al-Libi's 'Human Shield in Modern Jihad”.

The text is included in a widespread collection of Arabic Jihādī primers, named Haqübat al-mujāhid (II), compiled under the aegis of Abū Muhammad al-Maqdisī (b. 1379/1959), which used to be available on TṬP-affiliated websites for download. Its Urdu translation by Ḥāfiz 'Ammār Șiddīqī had been published in June 2004 as Kuffār par 'āmm tabāhī musalliṭ karne kī sharī hayșiyyat (Lahore, Dār al-Ishā'at al-Islāmiyya).

36 See Fahd, Risāla fi ḥukm, 12ff.; compare Bayhaqī, al-Sunan al-kubrā, 9:144 (ḥadīth 18,119); Majd al-Dīn ibn Taymiyya, al-Muntaqā fì l-ạkām al shariyyya, 741 (ahādīth 3,305-7).

37 See Fahd, Risāla fi ḥukm, ıff.; for his references, see 'Asqalānī, Fatḥ al-bāàī, 4:154ff.; 'Aynī, Umdat al-qārī, 14:375.

38 See Fahd, Risāla fi ḥukm, 15-21; for one of his numerous references, see Shāfi ī, al-Umm, $5: 591$. 
of the Prophetic precedent instead: the justification of the leadership claims of the Islamist militias and their respective command. It is somewhat remarkable that this subject was highlighted predominantly in the early days of the Resistance, ${ }^{39}$ while the only explicit statement in the later years appeared once again in Haqq Pāćūn of the Ittiḥād-i Islāmī barā-yi Âzādī-yi Afghānistān (IIAA), led by Sayyāf, ${ }^{40}$ suggesting that at that time they were about the only ones among the militias seeing a need to justify leadership claims in recourse to the Prophet. The argument runs in full conformity with the classical Islamist interpretation of Q 24:55, in which God declares those who believe and work righteous deeds to be His deputies on earth. ${ }^{41}$ For the anonymous author of this short article in question, the benchmark for believing and working righteous deeds is the Prophet Muhammad, ${ }^{42}$ which, so he concludes, had been most comprehensively embraced by the Pashtun mujähidin in the Afghan Resistance. At the same time, he dissociates their religiously justified leadership claims from mundane rule (saltanat; $v \bar{a} k m ə n \bar{\imath}$ ), which, so I assume, is implicitly aimed at the PDPA rule as well as the preceding parliamentarian system under Muhammad Davūd Khān and the Barakzay monarchy, with its last representative in Zāhir Shāh (d. 1386sH/2007) then biding his time in Italian exile. ${ }^{43}$ Here, too, the author follows standard Islamist rhetoric: while the intentions of even the PDPA cadres may be sound, the foundations on which their intentions rest are not, and such political systems consequently bound to fail. Therefore, following in the footsteps of the politician Muhammad is the only guarantor for a stable and benevolent sociopolitical framework.

Finally, especially in the later stages of the Resistance, when the mujāhidin made substantial progress not least thanks to US material support, Islamist actors now saw a golden opportunity to target the overall social fabric of Pashtun society which would necessarily clash with the alternative Islamist model of society that was to form the basis of the Islamic state to come. The matter was urgent: after all, it also needed to be determined how to deal with cadres and supporters of the PDPA and its ally, once the victory had been achieved. This, in

39 See, for instance, Sayyid Abū l-Ḥasan ['Alī] Nadvī, "Də Payghambar - ș - aw siyāsī lìdar farq (trans. Fažl Mawlā "Latūn")", Shafaq 1/1 (1358sh), 14 ff. and 44.

40 See "Narivāl də payghambar - șallā Allāh 'alayhi wa-sallam - də uṣūlo payravə tah tarbal har vakht nən zyātah aṛtiyā laray", Haqq Pāćūn 1/1 (1364SH/1406H), 4ff.

41 See here the elaboration of the khilāfat Allāh, vis-à-vis the historical khiläfat rasūl Alläh, by Mawdūdī as a classical Islamist core author in Hartung, A System of Life, 105-10.

42 See also "Kashshāf", "Də muḥammadī risālat rīx̌tīnūlī", Haqq Pāćūn 2/14-15 (1378sh ), $28 \mathrm{ff}$.

43 It seems that the anonymous author was well aware of the still immense support throughout Afghanistan for Zāhir Shāh and a return to the monarchy, which for many Afghans with no direct personal experience of this further distant past represented an idealised period of relative public security and stability. 
fact, is the context of a third Islamist reference to the Prophet, which, however, remained rather implicit in his portrayal as perfect role model.

In the editorial to the first issue of HiI-H's Shafaq magazine, the story of the beginning of Muhammad's public preaching has been retold, cast here as a challenge of an oppressive aristocratic (mulūkì) or ecclesiocratic (dārāān political system, which required upright personalities such as Muhammad's early companion 'Abd Allāh b. Mas'ūd daring to stand up for their faith in public. Still, the story of the early Islamic da'wa is not one of humility and forbearance, but rather of pugnaciousness, especially when it got correlated with contemporary - in this case Soviet - imperialism (isti'mār). ${ }^{44}$ The pragmatic sociopolitical culture in the Pashtun borderland was, by inference, blamed for a lax attitude towards political systems other than an Islamic one, which is why steadfast Muslims, that is, those organised in the HiI-H, need a systematic approach to redress this evil.

More implicit still is the critique of traditional sociopolitical structures in the Pashtun borderland in an article by a certain "Kashshāf", once again published in the Pashto-language Haqq Pāćūn of Sayyāf's IIAA. ${ }^{45}$ On the surface, the author just narrated the story of the conversation between the Prophet's later companion Mughīra b. Shuba with Cyrus, the Patriarch of Alexandria (al-muqawqis), on Muhammad's personality. ${ }^{46}$ Yet, the historical context of the story conveys some meaning with regard to the question of tribal loyalty vis-à-vis commitment to the supra-tribal community of Medina under the leadership of the Prophet. Mughīra namely had travelled to Egypt alongside a delegation of the Banū Mālik of Țāif and, enraged by what he perceived as disrespect towards him, killed them all. When offering a fifth of the booty to the Prophet, Muhammad rejected it, presumably on the ground that they had not been killed under an Islamic framework, but in inner-tribal rivalry. ${ }^{47}$

Given this wider context, resorting to a Prophetic example may well have served "Kashshāf" and his compatriots in the IIAA to challenge the centrality of tribal social patterns by reading the Prophetic precedence as a sociopolitical revolutionary programme, aiming at superimposing a more inclusive collective identity on the tribal ones prevalent in the Arab Peninsula during the formative period of Islam. This, it can be inferred, is also what would have to be overcome in Afghanistan, in order to, first, succeed in liberating the country

44 See "Jarliyo", "Payghām-i Shafaq", Shafaq 1/1 (1358sh), 4-8.

45 See "Kashshāf”, "Də muhạammadī risālat rīx̌tīnūlī", Haqq Pāćūn 2/14-15 (1378s H), $28 \mathrm{ff}$.

46 A classical reference to this story is Ibn Hudayda, al-Mișbāh al-muḍ̂, 2:120-23.

47 The historical event, having taken place around the time of the Treaty of Hudaybiyya, is prominently attested in Wāqidī, al-Maghāzī, 962-67; also e.g. Dhahabī, Siyar a clām al-nubalä, 3:23ff. 
from the grip of the PDPA or its successor and its Soviet allies, and, second, to provide a normatively grounded perspective on nation-building.

The Prophet, however, can hardly be reduced to his role as statesman and leader of a political community. For other significant, though less Islamist, Pashtun actors in the Afghan Resistance the aspect of the Prophet as the soundest spiritual guide on the path to salvation was apparently more crucial than his combat tactics, his supra-tribal societal vision, and his political leadership.

\subsection{The Prophet as Guide to Salvation: The Primacy of the Hereafter}

Ostentatious, the matter of tribal loyalty vis-à-vis the commitment to the supra-tribal community of believers in Islam was of crucial importance also within the predominantly rural representatives of Frontier Deobandiyyat in its militant variety, here prominently the circles around Ḥaqqānī and Khāliṣ. I would even go as far as arguing that for these actors, deeply steeped in the tribal culture of the Pashtun borderland themselves, this issue was of much greater and immediate importance than to the Islamists with their socialisation in the urban and multi-ethnic environments of Kabul, Herat, or Peshawar. Especially those tribally organised ethnic Pashtuns within the Resistance found themselves in a dilemma quite similar to that of the early Muslim community under the leadership of the Prophet Muhammad when confronted with their meanwhile hostile kinsfolk. Indeed, were the first Muslims not put in a conflict of loyalty when placed in a situation that caused them to militarily confront their own family members? Were not numerous of the muhäjirün quite reluctant to go to battle with the Meccans at Badr, as well as at Uhud and the trench at Yathrib, and required some persuasion by the Prophet to at least ease that internal conflict? ${ }^{48}$ Consequently, the issue of tribal loyalty and its conflict with the societal vision of the Prophet figured much more prominently in the publications of Frontier Deobandīs.

Yet, and this is a crucial difference to the images of the Prophet invoked by the Islamists, those by the Frontier Deobandīs were almost exclusively related to the early Meccan period in Muhammad's career, and, thus, revolving rather around his religious mission than his statecraft. Still, this does not imply that the respective images of the Prophet purported by this particular faction within

48 See here the examples of 'Umayr b. Humām and others, which Muhammad solved by promising those who would die in action to immediately become martyrs and ascend to the heavens, as narrated in Ibn Hishām, al-Sìra al-nabawiyya, 1:627; see also Muslim, Șahịh, 3:14, o14, hadìth no. 1, 789; 1509-11, hadìth no. 1, 901. 
the Afghan Resistance was entirely devoid of political allusions. Other than in the cases above, however, he is less presented as military commander and governor over a Muslim polity, but as reformer of the prevalent sociopolitical conditions in the Arab Peninsula. An anonymous author of the Żãźay tribe of Khost, a tribal configuration historically in direct competition with the Źadrān to which Haqqānī belonged, wrote a lengthy piece in the latter's $M a n b a^{c}$ al-jihäd Pashto journal, ${ }^{49}$ in which he castigated the sociopolitical, economic, and religious constitution of Mecca and the wider Hijāz prior to the advent of the Prophet. ${ }^{50}$ Very much in line with the extraordinary status which the Prophet enjoyed in the rural Muslim communities of the Pashtun borderland, ${ }^{51}$ the author then continues to tell of the auspicious signs around the birth of Muhammad which would later make it into what Katz calls the "mawlid narrative".52 By doing so, he implicitly invoked a simple two-step teleological model of societal development which follows much the binary jähiliyya/islām which became constitutive to Islamist systemic outlines, ${ }^{53}$ although he goes not as far as establishing a new kind of jăhiliyya as antagonistically co-existing with Islam, which is what Islamists were, and are, doing. For him, the miracles surrounding the birth of Muhammad are sufficient enough an indication that God had sent the ultimate saviour to end all the negative social, political, economic, and spiritual implications once and for all.

Other than the self-confident and urbane Islamists presented here, this is a subaltern voice which is well rooted in the cultural environment of the vast rural areas of the Pashtun borderland. In a terrain where the PDPA and its Soviet allies had patchy control at the best of times only, the adversary included prominently members of the local communities who showed signs of social, political, and religious infidelity. This has two major implications: a sociopolitical one, and a religious one. The first is strongly tied to the socio-economic, and therefore also political, stratification in the Pashtun borderland into what

49 There existed a distinct Arabic journal of the same name, beginning its publication in February 1990 and petering out some time after 1992.

50 See "Toriyālay Źāźay": "Də Ḥaẓrat Muḥammad (ṣ) nīkmərghah mīlād də basharī narəy də najāt aw sacādat zīray", Manba al-Jihād [Pashto] 2/3-4 (1369sh/1411H ), 12-14 and 47 .

$5^{1} \quad$ See Hartung, "'He's Just a Man!', 173-75.

52 See Katz, The Birth of the Prophet Muhammad, 6-62. Interestingly, the fact that Manbac al-Jihäd (Pashto) carried such a piece indicates that the relationship of the so-called Haqqānī network with Arab volunteers in the later stages of the Afghan Resistance, many of whom would become infamous as beacons of al-Qācida and maintain theological and legal positions emphatically close to those of Ibn Taymiyya (d. 728/1328), was much more complex and ambivalent as currently admitted: see prominently Brown and Rassler, Fountainhead of Jihad, 59-127.

53 See Hartung, A System of Life, $62-72$. 
Akbar S. Ahmad calls "seniors" (masharān) and "have-nots" (kasharān), ${ }^{54}$ while at the same time an illusive image of general egality in Pashtun communities is nourished and perpetuated. The former stratum is usually represented by the ranks of khän and malik, both distinguished by economic affluence and therefore also in possession of substantial social and political capital. Elsewhere I have argued that much of the religious mobilisation in the Pashtun borderland can be framed along this perpetual conflict between community leaders by virtue of material wealth and subalterns who emphasised their moral superiority instead. ${ }^{55}$ In this claim the representatives of the subaltern ethical paradigm were, and still are, bridging over to the religious implication: against the social reality, in which status is tied to "wealth and progeny" (māl wa-awlād), they posit Q 48:14-15 to point out the irrelevance of worldly gains for the passage to eternal bliss in the hereafter. Chief advocates of this view since the early twentieth century have been those associated with "Deobandiyyat"; 56 and it is consequently maintained by its representatives in the Pashtun borderland. Alongside the socio-economic and political critique articulated by Deobandīs in the region went the standard agenda of religious reform that "Deobandiyyat" in general stood for. In deliberate continuity to the somewhat patronising activities of the early nineteenth-century Tariqah-yi Muhammadiyyah around Sayyid Aḥmad Barelvī and Shāh Ismāîl Dihlavì (both killed 1246/1831) in the Pashtun borderland, ${ }^{57}$ this programme pivoted on the eradication of shirk and the realignment of religious beliefs and practices with the legal norms of Hanafi figh.

Both the sociopolitical and the religious criticism coincided in the basic assumption that the sociopolitical opportunism of the masharān provided for the erosion of apt religious norms, as well as leading the kasharān, who depended on them economically, to pay more heed to worldly matters than to the stable road map to salvation that the Qurān and the Prophetic sunna provide. ${ }^{58}$ This is the starting point for references of the Pashtun Frontier Deobandīs within the Afghan Resistance to the Prophet Muhammad, and in

54 See Ahmed, Pukhtun Economy and Society, 144.

55 See Hartung, "Of Pious Missions".

56 See Hartung, "Of Pious Missions"; also Hartung, "The Praiseworthiness of Divine Beauty".

57 See Hartung, "He's Just a Man!', $176-87$.

$5^{8}$ The sharp division between the followers of economic and political elites and those of a Sufi shaykh uncorrupted by the temptations of political and material power, epitomised in the two distinct social spaces "men's house" (hujrah) and "mosque/khānaqāh", had already been stressed by Barth, Political Leadership among Swat Pathans, 52-63 and 71-103. His perhaps most succinct remark in that regard is that "some villagers stay away from the men's house because they prefer to place exclusive trust in a Saint by joining the group which forms around him.... By creating a centre for instruction and conversation 
this framework his jihād was never dedicated at enhancing his position as political head of the new Muslim polity or military genius, but as emphatic dissemination of the Qurānic message only, consisting first and foremost in the eradication of shirk and kufr. ${ }^{59}$

Yet, adherents to Frontier Deobandiyyat were well aware that their respective criticism of the religiosity of those subaltern to them entails necessarily also a critique of the societal elite whose worldliness was clearly seen as the root of the evil. ${ }^{60}$ Because of this more empathetic take on the sociopolitical structures in the Pashtun communities from the bottom up, it does not really surprise that the strategy derived from the Prophetic example was not in the first place military subjugation, but rather an emphatic invitation to reform along Qurānic lines $\left(d a^{\prime} v a t\right)$. In an earlier article in the Pashto journal Manbac al-Jihād, a certain Mawlānā Bashār stressed that the Prophet had clearly devised a course of action, and, because Muhammad was portrayed as true enactment of especially the esoteric (bāțin̄i) Qurānic principles, to faithfully follow his approach means to obey God's command. In this context, again, the early Meccan period was invoked, during which the Prophet admonished the "masharān" among the Quraysh to forsake their wrong ways and embrace the Qur'annic message. In this context, the virtues of patience and persistence (șabr), sincerity (ikhlāss), and determination ('azm and hazm) became repeatedly stressed, ${ }^{61}$ not least by quoting the Prophet from around the time when he was exposed to the hostilities towards him by his fellow Meccans, because of his "publicising the din of God and calling thereto",62 saying: "By God, even if they put the sun in my right hand and the moon in my left hand on the condition that I abandon this matter, I will never abandon it until either God has made me victorious or I perish therein." 63

Khāliș went even further: in one of his poems, he tied sociopolitical status, "seniority" (masharəy), to religious obedience alone and castigates the boastful attachment to this world, stating that "on the Day of Resurrection, such mashar is a sinner", concluding that "who does not walk in the path of God Almighty,

in his house or in the local mosque, the Saint welds these separate devotees into a coordinated group" (56).

59 See Mawlānā "Bashār", "Də Ḥazrrat payghambar - șallā Allāh 'alayhi wa-sallam - jihādī risālat", Manba' al-Jihād [Pashto] 1/4-5 (13675H/1410H), 11-16.

6o See, for example, "Farmān-i nabavī: Jis se allāh awr jo ilāh se nahīṇ kar milegā", Nuṣrat al-Jihād 1/2 (1411/1990), 8ff.

61 See, for example, "Farmān-i nabavī: Awr yah fakhriyyah bāt nahịn he", Nușrat al-Jihād 1/1 (1411/1990), 10 and 16.

62 Ibn Hishām, al-Sìra al-nabawiyya, 1:265.

63 Ibn Hishām, al-Sìra al-nabawiyya, 266; quoted in Pashto translation in "Bashār" (see note 59$), 14$. 
a mashar he is not / a mashar is a mashar only if steadfast in the path of God". ${ }^{64}$ What that entails was somewhat elucidated in a series of articles, once more in the Pashto Manba' al-Jihād, on a number of events in the Prophet's life, again during the early Meccan period. ${ }^{65}$ All the examples presented in this series suggest that verbal propagation of the correct faith and emphatic calls to observance was indeed the preferred mode of working inside the borderland communities.

Yet, Mawlānā Bashār, in line with his above reading of the Prophet's sira, also allowed for the application of force in two instances: one, whenever words do not yield an insight into the truth, and another whenever the community of believers is under attack itself. ${ }^{66}$ While the latter is common sense in legal deliberations on "defensive jihā $d$ ", the former requires some more consideration, because, after all, one needs to establish the point in time when to hope for the words to sink in is over and force needs to be applied. Here we seem to enter a grey area, because this particular question did not get answered in recourse to the Prophet as role model. In fact, this is the area where da'vat-focussed "Deobandī pietism" 67 appears to overlap with both communal customs of tribal warfare and the above-outlined Islamist attitude towards jihād, a tightrope act perhaps most emblematically performed by Khāliṣ.

Besides his prose works, which are seemingly influenced by his readings of Islamist classics, his poetry is more ambiguous. There, Khāliș employed a semantic field which resonated well with an Islamist readership, using such Islamist core concepts as "revolution" and "Islamic governance", and reflecting the systemic battle with other political ideologies of the day. ${ }^{68}$ Besides, however, Khālis also spoke to a distinctly Pashtun tribal audience, in which common notions such as the sovereignty of the Pashtun lands or its tradition of stubborn resistance to any form of subjugation are equally invoked as references to distinct acts which, in the cultural context of the Pashtun borderland,

64 Khāliṣ, Damūnah aw dāne, 186ff. (Mashar-tob), lines 6 and 11ff.; also 'Azīz Allāh, Do Mawlavī Khäliṣ žvand, fann aw and, 182.

65 See Abū Hārūn, trans., "Də Rasūl Allāh də žvand las vraźay (I): Də Ka'bay dodanay joṛulo vraź", Manba al-Jihād [Pashto] 3/4 (1370SH), 44-46; "(II): Də ṛūmbanī vahyy vraź", Manba' al-Jihād [Pashto] 3/5 (137OSH), 18-21; “(III): Də Rīm də Țāyif vraź”, Manba' al-Jihād [Pashto] 3/7-8 (1370SH ), 46-48. Unfortunately, none of these articles bears any indication from which source and language Abū Hārūn had prepared his translations.

66 See "Bashār" (see note 59), 16.

67 See Hartung, "The Praiseworthiness of Divine Beauty", 359-61.

68 See Khāliṣ, Damūnah aw dāne, e.g. 49ff. (Islām asāsī qānūn), 61ff. (Inqilāb), 84 (Islām aw soshalezm), 91 (Soshalezm aw islām), 108ff. (Də Isti'mār nawkarān ćok dī?), 12off. (DəJihād mawqi' dah), and 124ff. (Qur'ānī ḥukm). 
all necessitate and justify an armed response. ${ }^{69}$ In this, Khāliṣ's approach coincided somewhat with that of Faẓl Vahīd, the "Hâajjī Șāhịib" of Turangzay (d. 1356/1937) in the Peshawar Valley, an early twentieth-century representative of Frontier Deobandiyyat around the "Shaykh al-Hind" Mahmūd al-Hasan.

The Haajjji Ṣahhib, namely, evolved into a chief enforcer of the sociopolitical changes that resulted from the religiously grounded mission of the Shaykh alHind and his circle in the Pashtun borderland. An advocate of the subalterns from whom he emerged, the Ḥajjjì Șāhịib challenged the self-serving political tactics of the masharān of old and new, and his efforts were consequently met with their resistance. In those cases where these community leaders would choose to ignore his verbal admonitions, the Haajjjī Ṣahhib mustered his own impromptu tribal militias (lax̌karünah) and saw through the rectification of his demands by way of armed force. ${ }^{70}$ Khālis would follow this model, even though the masharān of his time were less those in the rural Pashtun communities, but those having usurped the political power in Kabul. After a long period of only rhetorical confrontation ${ }^{71}$ from 1978 onwards the situation had escalated to the extent that only armed resistance remained an adequate response, to be staged by those whom he called "the clan of the Prophet" (Nabi $k h e l)$, thus again invoking the example of the Prophet Muhammad as benchmark of religious righteousness.

As we have seen, despite numerous overlaps, the worldviews of the two ideal-typically established main factions among the Pashtun actors within the Afghan Resistance - Islamists and Frontier Deobandīs - remained fundamentally distinct, as emblematically expressed in their respective references to the Prophet Muhammad as role model. Moreover, the example of the Ḥājji Ṣāhib of Turangzay also suggests a historical pattern underlying this distinction. This, in fact, is what is argued here, and in order to substantiate this claim, we need to go quite a bit back in time.

69 See Khāliṣ, Damūnah aw dāne, 169-72 (Pax̌tūn aw ghulāmī), 180-82 (Də pax̌tano sìmah), and $197 \mathrm{ff}$. (Ghadār). See also Ṭalāyī, Khāliṣ Bābā, 54-61.

70 See Qadir, Reforming the Pukhtuns, 28-31 and 39-56. Khan, "The Pashtoon Resistance", 25-28, discusses the British colonial strategies to co-opt local elites in the Pashtun tribal communities, or to even create new ones, which were major instances for the Hâjjji Ṣậịib’s oftentimes violent interventions.

71 In the early 195os, Khālis was employed by Radio Kabul to run a religious programme; in the mid-196os he took over the editorship of Payām-i Haqq, purportedly the first Islamic magazine in Afghanistan. In both these capacities, as well as in his early prose works, Khālis aimed as spreading a legally correct understanding of Islam and its necessary implementations in society. See 'Azīz Allāh, Də Mawlavī Khāliṣ žvand, fann aw and, eff. and $26 \mathrm{ff}$. 


\section{4}

\section{Antecedents: Two Ethical Paradigms}

In order to better understand origins as well as sociopolitical implications of the two distinct ideal-typical images of the Prophet Muhammad in the Afghan Resistance to the PDPA and the Soviet occupation, it pays to trace back in time the underlying ethnical dispositions which seem to be reflected in them. These dispositions, again, are discussed here as ideal-types, allowing for a much greater variety of them on the ground. Yet, most of them can be ascribed to one of two dominant and opposing ethical outlines which are deeply rooted in Pashtun society: one is an elite-centric ethics, which I shall call "princely ethics", while the other one is one that reflects more subaltern positions, and will therefore be labelled "subaltern ethics". Both are, in fact, vividly present in various cultural practices throughout the region, for instance in everyday poetic allusions, proverbs, or impromptu rhymes (tappay), thus constituting what Gramsci called historical "traces" of a reflexive sociopolitical identity. ${ }^{72}$

The emergence of both ethical paradigms is closely linked to the geopolitical situatedness of the "Pashtun borderland" in a kind of longue durée, and reflects thus also the position and attitude of borderlanders towards imperial powers, ultimately contributing to the ethnogenesis of the Pashtuns. Originally highly mobile communities who mediated the long-distance trade between Central Asia and the Indian subcontinent, ${ }^{73}$ their eventual settlement in the foothills of the Hindukush was the result of the displacement of marginal communities in the course of imperial expansions in Iran, Central Asia, and India. ${ }^{74}$

Situated at the frontier between empires, they constituted a critical mass for the maintenance of territorial integrity, and as such were of high strategic interest to imperial powerholders. Consequently, these powerholders, such as the Mughal establishment, attempted to create subservient local elites to represent imperial interest in the mountainous borderland, while at the same time finding an administrative category for those largely autonomous communities, to fit them into their imperial framework. The result of such

72 See Gramsci, Quaderni del carcere, 2:1376: "The starting point is the consciousness of what one really is, and is 'knowing thyself' [conosci te stesso] as a product of the historical process to date which has disposited in you an infinity of traces [un'infinità di tracce], without leaving an inventory" (trans. J. A. Buttigieg).

73 See Digby, War-Horse and Elephant; Gommans, The Rise of the Indo-Afghan Empire, 77-83 and $113-43$.

74 See, for example, the case of the Yūsufzì kinship grouping, who are reported to have been displaced from the area around Kandahar and pushed to the mountainous region further north, where they are concentrated nowadays, in Mu'azzam Shāh, Tavārīkh-i Hāäiz Raḥmat Khānī. 
external categorisations was an increasingly solid ethnic self-understanding of these communities as "Pashtun",75 yet not, as intended, as a category in the imperial framework of the Mughals, but one of self-confident difference. This was perhaps most emblematically expressed by Khūshḥall Khān Khattak (d. 1100/1689), formerly a faithful vassal of the Mughal ruler Shāhjahān, who in turn had built up on his father's strategy to elevate certain tribal communities over others in exchange for their compliance with Mughal imperial interest in the region. ${ }^{76}$ Yet, when Khūshhāl claimed to not having been treated appropriately by Awrangzīb 'Ālamgīr, Shāhjahān's successor to the Mughal throne, he reinvented himself as an ardent opponent to the Mughals and a champion of the Pashtuns, stating that "For this state of things, no other resolve can be seen / than that the Mughals be annihilated, or the Pashtuns undone".77

Indeed, Khūshḥāl is nowadays regarded by many Pashtuns as core reference for what it means to be "Pashtun", and his earlier affiliation with the Mughals, to whom "from the very beginning / [he] ha[s] been faithful and loyal",78 rather downplayed. While there is good reason to agree with the view that it took a representative of the tribal elite to establish the language as a literary idiom, ${ }^{79}$ we need to be aware that the perspective is essentially an elitist one that does not negotiate with subaltern voices within the Pashtun linguistic universe. Their alter ego were, and are, rather competing sociopolitical elites, such as the Mughals and, later on, the British colonial establishment, which is not least reflected in the fact that Khūshḥāl had chosen Persianate - Mughal - forms of poetic presentation over local Pashtun ones. Of special significance in this regard is Khūshḥāl's qașīdah "Poetry is the Discharge of Men" (shi'r hayza al-rijāl day), because it comprises all the core themes in this discourse: the relationship between mundane and divine beauty, imperial economy and politics

75 The historiographic process of ethnic distinction began with 'Abbās Khān Sarvānī's (d. after 988/1580) account of the reign of Shīr Shāh Sūrī, commissioned by Mughal pādishāh Akbar, and was soon supplemented by a genealogical account of imperial chronicler Ni`matallāh Haravī (d. ca. 1040/163o), which rooted the label "Afghan" in a certain - though empirically little sustainable - pedigree. Haravi's image was soon appropriated by literate representatives of the borderland communities, as indicates the portrayal by Akhūnd Darvīzah (d. 1048/1638), originally from Nangarhar. See Sarvānī, Tärīkh-i-Sher Shāhīi, 1:2ff.; Haravī, Ṭabaqāt-i akbarī; Darvīzah, Tažkirat al-abrār, 58-62.

${ }_{7} 6$ This applies very much to the Khattak, a kinship community that claims the region of Karak as their ancestral territory. See Kākākhel, Pax̌tānah do tārīkh pah ranrāā kx̌e, 697-99.

77 Khān Khațak, Armaghān-i Khūshḥāl, 19, line 6; see also 16-29.

78 Khān Khaṫak, Armaghān-i Khūshḥāl, 11, line 8.

79 I am most grateful to James Caron (soAs, University of London) for generously sharing with me his thoughts on this matter. 
vis-à-vis communal ones, youthful virility that, nonetheless, requires disciplining and channelling into concerted action within a patriarchal framework. ${ }^{80}$

The princely ethics which emerges from Khūshhạal's versatile poetry pivots on the notion of "honour" (nang), cast as the ability to contain the virtue of the female members of one's household (sharm). Such constructed honour, in turn, feeds into a hierarchical worldview: to possess honour becomes thus equivalent to high social, political, and economic status. Such a hierarchy, in turn, is inevitable and therefore highly desirable, as Khūshhāl argued in reference to the Prophet Muhammad, somewhat forecasting above Islamist references of the late twentieth century: "When Muhammad's time arrived / feared were the Arabs for [their] courage. Success depends on the leader [sardār] / and nothing else, know this, my son!"81

The projected hierarchy does not even stop at the local mechanisms of negotiation and decision-making: even the jirgah, oftentimes romantically portrayed as an highly egalitarian local institution, is, besides the little acknowledged exclusion of females, subordinate to the ultimate judgement of a member of the sociopolitical elite. ${ }^{82}$ Needless to stress that Khūshḥāl relied less on religious rhetorical figures to sustain such a hierarchical worldview; his shorter qașidahs on divine and Prophetic attributes seem to reflect rather his familiarity with prominent literary tropes in Pashtun poetic expression. ${ }^{83}$

This, in fact, was quite the opposite for the representatives of the other ethical paradigm, that of subaltern authors, ${ }^{84}$ of whom 'Abd al-Rạmmān "Raḥmān Bābā" Mohmand (d. 1123/1711) from a small village near Peshawar appears to be considered the epitome. Indeed, in his verses Raḥmān Bābā stressed qualities oftentimes associated with the Prophetic mission of Muhammad: mercy (məhrbānī, or rahmat), justice ('adālat), and egality (musāvāt, or inșāf). One's social, and subsequent political, status, in turn, emerges from the ability to embody these qualities: when referring to a mashar who, "in parcelling

8o See Khān Khaṫak, Armaghān-i Khūshḥāl, 6-12.

81 Khān Khațak, Armaghān-i Khūshḥāl, 725, lines 3 ff.

82 See Khān Khațak, Dastār'nāmah, 93 ff.

83 See Khān Khațak, Dastār'nāmah, 2-5; and, for example, Gohar, "Pax̌to kx̌i də na'tiyyah shā'irəy irtiqā̄", 177-211.

84 These subaltern authors coincide with what Gramsci, Quaderni del carcere, 2:1392, 3:1513, and 2283ff., has alternatively called "organic intellectuals" (intellettuali organici), "embedded historians" (storici integrali), or "community writer" (pensatori collettivo), while Caron, "Social Inequality", 1, calls them "peasant intellectuals", in reference to the title of Steven M. Feierman's work on Tanzania from 199o. See also Caron, "Reading the Power". I am grateful to my former colleague Cosimo Zene (London) for his elaboration of Gramsci's concept. 
out water [rights] he is not just, even if his hand grips pages of the Book", ${ }^{85}$ Raḥmān Bābā combined socio-economic critique with religious ethics. Thus, he sustained a trope that, so Ibrāhīm 'Ațāyī claims, had already been a major driver for the millenarian movement of Bāyazīd Anșārī, better known as the "Pīr Rox̌ān" (d. after 988/1580), ${ }^{86}$ consequently resulting in a barrage of polemical remarks on their subaltern religiosity by privileged members of the Mughal establishment. ${ }^{87}$

Here, it appears that it were authors like the Pīr Rox̌ān, ${ }^{88}$ and even more so Raḥmān Bābā, who established an almost causal relationship between social, economic, and political egalitarianism, resistance to perceived injustices in all these departments, and "Pashtun-ness": "Tenant he is, sharecropper he was, he will rise to be Pashtun / even if a cobbler or butcher by origin. Speaking mildly has no effect on him [i.e. the landlord] / since in his heart is neither shame nor hijäb."89 Consequently, "Pashtun" can only be whoever resists injustice and maintains a strong social conscience; more still, a "Pashtun" is essentially subaltern. ${ }^{90}$

Both ideal-typical ethic frameworks in the Pashtun-dominated borderland, I content, are one, if not the, reason for perpetual local conflict that can be traced all the way to the level of any given village community. These communities, which emphatically present themselves to the outside as "essentially egalitarian", are this way divided into those who regard fraternisation with the strong and powerful as primary expression of their ethnicity and, therefore, as commendable, and those who stress just the opposite. Violent expressions

85 Raḥmān Bābā, Dìvān-i 'Abd al-Raḥmān Bābā, 110, lines 13 ff.

86 See 'Ațāyī, Də pax̌tānay qabīlo ... qamūs, 295. This view on the socio-economic constitution of the Peshawar Valley has been taken over by Nichols, Settling the Frontier, 21.

87 The most prominent and influential pejorative religious appraisal of the Rawshanniyyah was Badāunī, Muntakhab al-tavārīkh, 2:241-43, from which distinct phrases have been adopted verbatim by Haravī, Ṭabaqāt-i akbarī, e.g. 2:398. Badā’unī's polemics, however, including the mock epithet "Pīr of Darkness" (pīr-i tārīk), were preceded almost immediately by Darvīzah, Tažkirat al-abrār, 31ff.; Darvīzah, Makhzan al-islām, 155 ff. See also Hartung, "Of Pious Missions", 7-11.

88 See prominently Anșārī, Khayr al-bayān, 206: "Some involve themselves in the work of farming, or in market-trade, or the herdsman's trade of cattle [da karlīyā da bāzar-gānay $y \bar{a}$ də povandi-kaləy], or go as far as servitude to kings, or other professions, for the accumulation of wealth [māl-gird], whether permissible or dubious, or [even] prohibited". See also Anșārī, Khayr al-bayān, 414-19.

89 Raḥmān Bābā, Dìvān-i 'Abd al-Rahmmān Bābā, 111, lines 17-20.

9o This results in the frequently observable fact that subaltern behavioural patterns are widely approved of as "Pashtun" regardless of the actual ethnicity of the person in question, while elitist conduct is openly referred to as "Punjabi". 
of this conflict have frequently occurred over time, and still do. ${ }^{91}$ Now, if we take this line of argument forward, then the two distinct kinds of references to the Prophet by the leading Pashtun representatives of the Afghan Resistance between roughly 1978 and 1992 follow the same trajectory.

The elitist thinking of the various Islamist organisations, which originated in a culturally and ethnically more diverse urban context, were clearly reflected in their respective images of the Prophet Muhammad as a warlord and politician, in other words, a member of a societal elite that is therefore axiomatically predestined to lead the community in a top-down fashion. Indeed, it is no surprise that it were the leaders of the various Islamist tanzimant who would almost instantly after the ousting of the Soviet army in 1989 and that of the Hizb-i Vațan-turned-PDPA regime in 1992 assume political top positions, all agreed upon in the so-called Peshawar Peace Accord, in which the claims for the new government of Afghanistan were parcelled out. Burhān al-Dīn Rabbānī served between 1992 and 2001 as president of Afghanistan, Sayyāf as his vice president, Hikmatyār between 1993 and 1994, as well as 1996 and 1997, as prime minister, Ahmad Shāh Mas'ūd between 1992 and 1993 as minister of defence, and Rabbān̄̄'s Jam'iyyat-i Islāmī-yi Afghānistān representative in Herat, Ismāīl Khān (b. 1365/1946), as governor of Herat Province between 1992 and 1997 and, again, between 2001 and 2004, before being appointed minister of water and energy of the Karzay administration between 2004 and 2013.

On the other end of the spectrum, we find the leaders of militias associated with what I call "Frontier Deobandiyyat", and who stayed at least formally aloof from political offices. Instead, they maintained and expanded their local powerbases, be it in Jalalabad and the wider Nangarhar Province, as was the case for Khāliș, or in the Loyah Paktiya region, as for Ḥaqqānī. When the Islamist militias, here first and foremost the HiiI-Ḥ and Mas'ūd's Shūrā-yi Naẓār, battled in 1992 without any mercy and consideration for the civilian population of Kabul for mere power and dominance, ${ }^{92}$ they were in a way echoing Khūshḥāl's poetic emphasis on a manly recklessness in battle as the ultimate expression of status-defining honour. Actors of a conservative rural and descentconscious background, like Khāliṣ and Ḥaqqānī, stressed more social values of an increasingly romanticised "Pashtun Code of Honour" (pax̌tūnvalī), ${ }^{93}$

91 See my respective argument in Hartung, "Of Pious Missions".

92 See Dorronsoro, "Kabul at War", 6.

93 This rather loose concept, which has been around for a while as an expression of socially acceptable conduct that may vary according to the respective context, had been embraced by Afghan nationalist intellectuals. A case in point is Qiyām al-Dīn Khādim (d. 1358sh/1979), leading member of the leftist Vīx̌ Zalmiyān movement of the late 1940s, 
such as hospitality (melmastiyā, or melmah pālanah), provision of sanctuary (panāh), and a willingness to sacrifice for the sake of others (qurbānī), ${ }^{94}$ all of which can be derived from a religiously charged notion of "justice". In fact, the only recently published collection of Khāliș's poetry indicates a strong emphasis on all these tropes. ${ }^{95}$ Unsurprisingly, these poems read well together with his nat poetry in which the Prophet Muhammad appears as perfect embodiment of all those social values. ${ }^{96}$

\subsection{Conclusion}

In hindsight of the looming downfall of the PDPA/Hizb-i Vatan regime and the humiliating defeat of the Soviet army by initially badly equipped Afghan militias, internal conflict within all those groups in what has been called here the Afghan Resistance became increasingly apparent. These contestations among the winning parties ran first and foremost along ethnic and denominational lines. Still, tension also arose within the ethnically Pashtun and denominationally Sunnī groups within the entire Resistance, reflecting, as it has been argued here, two historically developed distinct ethical frameworks that respond to socio-economic and subsequent political particularities in the Pashtun communities along the national border between Afghanistan and Pakistan. Both frameworks have been embraced by distinct factions within the Pashtun contingent of the Afghan Resistance, reflected in distinct images of the Prophet Muhammad as emerges from the publications of the various respective groups.

to whom we owe the monograph Pax̌tūnvalī (Kabul, Də pax̌to tolānah 1331SH), the first attempt to enshrine the constituents of pax̌tūnvalī independent from the respective context in which they are applied. In numerous ethnographic studies, however, pax̌tūnvalī has been ascribed a reality which I find difficult to relate to, but which have sustained the romantic image of an all-comprehensive code. See, for instance, Spain, The Way of the Pathans; Steul, Paschtunwali; Nūrzay, Pax̌to aw pax̌tūnvalī. A slightly more considerate view is presented by Barth, Afghanistan og Taliban, 28-31. For a more detailed critique see Hartung, "A Taliban Legal Discourse on Violence", 146-53.

94 The concept of qurbānī is in fact central to the discussion of martyrdom in Deobandī circles in the Frontier, while it is widely absent in the Islamist discussions on the same issue. See, for instance, Mīrzākhel, "Də Shahādat islāmī falsafah", Manba` al-Jihād [Pashto] 2/9 (1369sh), 10-12; anon.: "Fazāyil-i shahīd", Haqq Pāćūn 2/5-6 (1365sh), 7 ff.; anon.: "Də Shahīd armān", Haqq Pāćūn 2/5-6 (1365sH), 9ff.; cf. anon.: "Shahīd dar islām", Mīsāāq-i Khün 2/2-3 (1366sh/1407H), 108-11.

95 See Khāliṣ, Damūnah aw dāne, 104-7 (Hurriyat aw musāvāt), 154ff. (Mīnah aw insāniyyat), 205ff. (Də bashar də khayr lapārah), and 218-20 (Musāvāt).

96 See Khāliṣ, Damūnah aw dāne, 29, 36-42, 144-47, and $203 \mathrm{ff}$. 
The first group were ideal-typically cast as "Islamists", represented predominantly by the organisations led by Gulbuddīn Hikmatyār and 'Abd al-Rabb Rasūl Sayyāf, the second as "Frontier Deobandīs" of the militant variety, personified in the respective groups led by Jalāl al-Dīn Haqqānī and Muḥammad Yūnus Khāliṣ. For the urban and openly elitist Islamists, Muhammad was conducive as role model of a political and military leader; their references were subsequently on the Medinan phase of the Prophet's life. The Frontier Deobandiss, in turn, staged themselves as embodiment of rural subalternity, and stressed consequently the image of the Prophet as one who holds fast to the truth, despite seriously adverse circumstances which could have easily cost Muhammad his own life.

Nonetheless, we need to acknowledge that also the Frontier Deobandīs had an elitist agenda, aiming at redressing widespread religious beliefs and practices in the rural Pashtun communities which they saw not warranted from a textual perspective. As perhaps most severe manifestation of this distinct form of socio-religious elitism would eventually emerge the movement of the Taliban during their reign over the entire Afghanistan between 1996 and 2001, as clearly indicated by their normatively grounded religious decrees. It therefore appears that explicit references to the Prophet Muhammad as a role model for this or that point to elitist persuasions whatsoever: both, Islamists and Frontier Deobandīs, employed images of the Prophet as benchmark for proper belief and conduct, vis-à-vis a broad range of such beliefs and practices locally acknowledged as conducive for the maintenance of the societal fabric of these communities. As such, the Resistance in which the Islamists and Frontier Deobandīs were both actively involved was, especially in the case of the latter, not exclusively confined to overthrowing an oppressive communist regime and its allies, but also to overcome locally established forms of religiosity for which they saw no textual corroboration.

\section{Acknowledgements}

Besides the DFG/ANR-funded project "The Presence of the Prophet: Muhammad in the Mirror of His Community in Early Modern and Modern Islam", the research for this chapter was substantially made possible through my formal involvement in the ERC-funded research project 693457 "Private Pieties, Mundane Islam and New Forms of Muslim Religiosity: Impact on Contemporary Social and Political Dynamics" (Institute of Social Anthropology, University of Goettingen, Germany). 


\section{Bibliography}

\section{Primary Sources ${ }^{97}$}

'Abd Rabbih, N. Z. 'Abd Rabb al-Rasūl Sayyāf: Qā’id al-jihād al-afghānī, Amman, Dār al-Ḍiyā' li-l-Nashr wa-l-Tawzī‘ 1987 .

Akoṛavī, M. 'Abd al-Ḥaqq. Fatāvā-yi ḥaqqāniyyah, 6 vols, ed. Mukhtār Allāh Ḥaqqānī, Akoṛah Khațak, Mu’tamar al-Muṣannifīn-i Dār al-'Ulūm Ḥaqqāniyyah, 2002.

Anșārī, Bāyazīd. Khayr al-bayān, ed. M. 'A. Qāsimī, Chaman, Pax̌to Adabī Tolānah, 1987. 'Asqalānī, A. b. 'A. b. Ḥ. Fatḥ al-bārī sharh Ṣaḥị̣ al-Bukhārī, 13 vols, ed. 'A. 'A. 'A. b. Bāz, Beirut, Dār al-Ma'rifa, 1959.

'Aynī, B. D. A. M. 'Umdat al-qārī sharh Ṣaḥịh al-Bukhārī, 25 vols, ed. 'A. M. M. 'Umar, Beirut, Dār al-Kutub al-'Ilmiyya, 2001.

'Azīz Allāh, Ḥ. Do Mawlavī Khāliș žvand, fann aw and, Kabul, self-published, 1386sH.

Badāunī, 'A. Q. Muntakhab al-tavārīkh, 3 vols, ed. M. A. 'Alī, Tehran, Anjumān-i Așār va Mafākhir-i Farhanḡ̄, 2001.

Bayhaqī, A. B. A. al-Sunan al-kubrā, 10 vols, ed. M. 'A. Q. 'Ațā, Beirut, Dār al-Kutub al-'Ilmiyya, 2003.

Darvīzah, Akhūn[d]. Makhzan al-islām, Delhi, Mațba' Fayẓ-i ‘Āmm, 1885.

Darvīzah, Akhūn[d]. Tažkirat al-abrārva l-ashrār, Peshawar, Islāmī Kutub'khānah, n.d.

Dhahabī, Sh. D. M. Siyar a ‘ām al-nubalā', 11th ed., 25 vols, ed. Sh. Arna’ūṭ and Ḥ. Asad, Beirut, Mu'assasat al-Risāla, 1996.

Fahd, N. b. Ḥ. Risāla fì hukm istikhdām al-damār al-shāmil didd al-kuffār, 2003. Accessed o2 September 2021. https://justpaste.it/ja5n.

Ḥaqqānī, M. 'Abd al-Qayyūm. Savānih-i shaykh al-ḥadīs Hažrat Mawlānā Abd al-Haqqraḥmat Allāh 'alayhi, Nowshera, al-Qāsim Akedimī, 2001.

Haravī, N. D. A. b. M. M. Ṭabaqāt-i akbarī, 3 vols, ed. B. De and M. H. Husayn, Calcutta, Maṭba'-i Baptist Mīshan, 1911-35.

Ibn 'Abd al-'Azīz, 'A. Q. al-'Umda fì i'dād al-'udda li-jihād fì sabīl Allāh ta'ālā, Amman, Dār al-Bayāraq, 1999.

Ibn Hishām, 'A. M. al-Sīra al-nabawiyya, 2nd ed., 2 vols, ed. M. al-Saqqā et al., Cairo, Mușțafā al-Bābī al-Ḥalabī, 1955 .

Ibn Ḥudayda, A. 'A. M. al-Mișbāh al-muḍ̂̀ fì kuttāb al-nabī al-ummī wa-rusulihi ilā mulūk al-arḍ min 'arabī wa-'ajamī, 2nd ed., 2 vols, ed. M. 'Aẓīm al-Dīn, Beirut, 'Ālam al-Kutub, 1985 .

Khāliṣ, M. Muḥammad Yūnus. Damūnah aw dāne (shi'rī tolgah), nnd ed., Peshawar, Də Dānish Khpərandviyah Tolanah, 1393s H.

97 The author is much indebted to the editors of this volume to allow here for an exception regarding the spelling of first names in the bibliography. 
Khān, 'A. 'A. "Pah Afghānistān ke də jihād də lumṛan̄̄ 'amaliyāt aw də kamūnistāno pah muqābil ke də 'ulamā’o paćūn”, Manba' al-Jihād [Pashto] 1/4 (1368s H/1989), 17-22.

Khān Khaṫak, Khūshkhāl. Dastārnnāmah də Khūshḥāl Khaṫ̇ak, Kabul, Də Pax̌to Tolanah, 1345sH.

Khān Khaṫak, Khūshkḥāl. Armaghān-i Khūshḥāl, 2nd ed., ed. M. S. Rasūl "Rasā", Peshawar, Yūniwarsitī Būk Ejensī, 2001.

Madanī, Muhammad Asrār, ed. Yād: Shaykh al-tafsīr va l-hadīs Mawlānā Ḋāktar Shīr 'Alī Shāh Madan̄̄ - rḥ: ḥayāt va khidmāt, Akoṛah Khaṫ̇ak, Mu’tamar al-Muṣannifīn-i Dār al-'Ulūm Ḥaqqāniyyah, 2016.

Majd al-Dīn Ibn Taymiyya. al-Muntaqā fì l-ahkām al-shariyya min kalām khayr al-bariyya - șallā Allāh 'alayhi wa-sallam, ed. Ṭ. b. 'A. b. Muhammad, Dammam, Dār Ibn Jawzì, 2008.

Mu'azzam Shāh, P. Tavārīkh-i Hāafiz Raḥmat Khānī: Afghān qabāil awr unke tārīkh, Urdu trans. Khān Rawshan Khān, Peshawar, Pashto Akedīmī, 1976.

Muslim b. al-Ḥajjāj, A. Ḥ. Șaḥịh Muslim, 5 vols, ed. M. F. 'Abd al-Bāqī, Beirut, Dār Iḥyā' al-Turāth al-'Arabī, 1954.

Niyāzī, Ghulām Muḥammad. Ma’ākhiz-i duvvum-i fiqh-i islāmī, Kabul, Shu'bah-yi Nasharāt-i Qavānīn va Kutub, Mudīriyyat-i 'Umūmī-i Nashriyāt-i Vizārat-i ‘Adliyyah, 1344SH.

Rabbān̄̄, Burhān al-Dīn. Irshād-i jihād, Tehran, Chāp'khānah-yi Khawshah, 1369s H.

Rabbānī, Burhān al-Dīn. Āmūkhtānihāyì dar masīr-i inqilāb-i islāmī, 2nd ed., Kabul, Anjumān-i Navīsandigān va Sakhnūrān-i Jamiiyyat-i Islāmī-yi Afghānistān, 1372SH.

Raḥmān Bābā. Dìvān-i 'Abd al-Raḥmān Bābā, ed. M. 'Abd al-Qādir, Peshawar, də Pex̌avar Yūnīvarsitī, Pax̌to Akedīmī, 1963.

Saharī, D. Jihād dar Kunar'hā, Peshawar, Jaddūn Press, 1368s H.

Sarvānī, 'A. Kh. Tārīkh-i-Sher Shāhī [sic], 2 vols, ed. S. M. Imān al-Dīn, Dacca, University of Dacca, 1964.

Shāficī, I. M. b. I. K. al-Umm, 11 vols, ed. Dr. R. F. ‘Abd al-Muțalib, al-Manșūra, Dār al-Wafā', 2001.

Ṭalāyī, 'Abd al-Kabīr. Khāliṣ Bābā qadam pah qadam, Islamabad, Də Iḥsān Khpərandviyah Tolanah, 139 osh.

Wāqidī, M. b. 'U. K. al-Maghāzì li-l-Wāqid̄̄, ed. M. Jones, Beirut, 'Ālam al-Kutub, 1984.

\section{Secondary Literature}

Ahmed, A. S. Pukhtun Economy and Society: Traditional Structure and Economic Development in a Tribal Society, Abingdon and New York, Routledge, 1980.

Alimia, S. "Performing the Afghanistan-Pakistan Border through Refugee ID-Cards", Geopolitics 24/2 (2018), 391-425.

Arnold, A. Afghanistan's Two-Party Communism: Parcham and Khalq, Stanford Hoover Institution Press, 1983. 
'Askar, M. A., The Will Not to Count: Technologies of Calculation and the Quest to Govern Afghanistan, PhD diss., McGill University Montreal, 2019. https://escholarship .mcgill.ca/concern/theses/2514nq7oc.

Ațāyī, M. Ibrāhīm. Də pax̌tānay qabīlo də ḥuqūqū, jazāyū, tacāmulì iștilāhāàto qāmūs, Kabul, Də Pax̌to Ćeṛano Nạ̣ivāl Markaz, 1357s H.

Barth, F. Political Leadership among Swat Pathans, London, The Athlone Press, 1959.

Barth, F. Features of Person and Society in Swat: Collected Essays on Pathans, London and Boston, MA, Routledge \& Kegan Paul, 1981.

Barth, F. Afghanistan og Taliban, Oslo, Pax Forlag, 2008.

Brachman, J., and A. Warius. "Abu Yahya al-Libi's 'Human Shield in Modern Jihad", CTC Sentinel 1/6 (2008), 1-4.

Brown, V., and D. Rassler. Fountainhead of Jihad: The Haqqani Nexus, 1973-2012, London/ New York, Hurst/Oxford University Press, 2013.

Caron, J. "Reading the Power of Printed Orality in Afghanistan: Popular Pashto Literature as Historical Evidence and Public Intervention", Journal of Social History 45/1 (2011), 172-94.

Caron, J. "Sufism and Liberation across the Indo-Afghan Border: 1880-1928", South Asian History and Culture 7/2 (2016), 135-54.

Caron, J. "Social Inequality and Ideological Circulation in Eastern Afghanistan, 19301960: Oral Publics for and against the Patriarchal State", in S. M. Hanifi, ed., Power Hierarchies and Hegemony in Afghanistan: State Building, Ethnic Minorities and Identity in Central Asia, London and New York, I. B. Tauris (forthcoming).

Chakrabarty, D. "Invitation to a Dialogue", in R. Guha et al., eds, Subaltern Studies: Writings on South Asian History and Society IV, New Delhi, Oxford University Press, 1985, 364-76.

Digby, S. E. War-Horse and Elephant in the Dehli [sic] Sultanate: A Study of Military Supplies, Oxford, Oxford University Press, 1971.

Dorronsoro, G. "Kabul at War (1992-1996): State, Ethnicity and Social Classes", SAMAJ South Asia Multidisciplinary Academic Journal (2007), http://samaj.revues.org/212.

Dudoignon, S. A. The Baluch, Sunnism and the State in Iran: From Tribal to Global, London, Hurst, 2017.

Fuchs, S. W. Proper Signposts for the Camp: The Reception of Classical Authorities in the Ǧihādī Manual al-'Umda fī I'dād al-'Udda, Würzburg, Ergon, 2011.

Fuchs, S. W. "Glossy Global Leadership: Unpacking the Multilingual Religious Thought of the Jihad", in N. Green, ed., Afghanistan's Islam: From Conversion to the Taliban, Oakland, University of California Press, 2017, 189-206 and 299-307.

Gayer, L. Karachi: Ordered Disorder and the Struggle for the City, London/New York, Hurst/Oxford University Press, 2014.

Gohar, M. I. "Pax̌to kx̌i də na'tiyyah shāiirəy irtaqā̄", PhD diss., University of Peshawar, 2001. 
Gommans, J. J. L. The Rise of the Indo-Afghan Empire c. 1710-1780, Leiden, Brill, 1995.

Gramsci, A. Quaderni del carcere: edizione critica, 2nd ed., 4 vols, ed. V. Gerratana et al., Turin, Giulio Einaudi, 1977.

Green, M. E. "Rethinking the Subaltern and the Question of Censorship in Gramsci's Prison Notebooks", Postcolonial Studies 14/4 (2011), 387-404.

Grima, B. Secrets from the Field: An Ethnographer's Notes from Northwest Pakistan, Karachi, Oxford University Press, 2005.

Hartung, J.-P. A System of Life: Mawdūdī and the Ideologisation of Islam, London/New York, Hurst/Oxford University Press, 2013.

Hartung, J.-P. “The Praiseworthiness of Divine Beauty: The 'Shaykh al-Hind' Mahmūd al-Hasan, Social Justice, and Deobandiyyat", South Asian History and Culture 7/4 (2016), 346-69.

Hartung, J.-P. "Of Pious Missions and Challenging the Elders: A Genealogy of Radical Egalitarianism in the Pashtun Borderscape", Geopolitics 24/2 (2018), 308-43.

Hartung, J.-P. “He's Just a Man!': Pashtun Salafists and the Representation of the Prophet", Die Welt des Islams 6o/2-3 (2020), 170-204.

Hartung, J.-P. "A Taliban Legal Discourse on Violence", in M. Baig and R. Gleave, eds., Violence in Islamic Thought: From European Imperialism to the Post-Colonial Era, Edinburgh, Edinburgh University Press, 2021, 123-59.

Kākākhel, S. Bahādur Shāh Ẓafar. Pax̌tānah do tārīkh pah ranṛā kx̌e: do 550 q-m nah do 1964 pūre, Peshawar, Yūnivarsitī Buk Ejansī, 1965.

Kākākhel, S. V. ‘A. Sh. Pōr șāḥib-i Mānkī-yi sharīf Sayyid Amīn al-Hasanāt awr unkī sìāsī jadd va juhd, Islamabad, Qawmī Idārāh barā-yi Taḥqīq-i Tārīkh va Śaqāfat, 199o.

Katz, M. H. The Birth of the Prophet Muhammad: Devotional Piety in Sunni Islam, London and New York, Routledge, 2007.

Khan, A. "The Pashtoon Resistance against the British Raj, 1897-1947", PhD diss., Quaid-i-Azam University Islamabad, 2014.

Ludden, D. "A Brief History of Subalternity", in D. Ludden, ed., Reading Subaltern Studies: Critical History, Contested Meaning and the Globalization of South Asia, London, Anthem, 2002, 1-39.

Marsden, M. Living Islam: Muslim Religious Experience in Pakistan's North-West Frontier, Cambridge, Cambridge University Press, 2005.

Nedza, J. Takfï im militanten Salafismus: Der Staat als Feind, Leiden, Brill, 2020.

Nichols, R. Settling the Frontier: Land, Law and Society in the Peshawar Valley, 1500-1900, Karachi, Oxford University Press, 2001.

Nūrzay, 'Abd al-Halīm. Pax̌to aw pax̌tūnvalī: do pax̌tāno do najāt lār, Kabul, Larāwbar, $1390 \mathrm{OH}$.

Olesen, A. Islam and Politics in Afghanistan, Abington, Routledge, 1995. 
Qadir, A. Reforming the Pukhtuns and Resisting the British: An Appraisal of the Haji Sahib Turangzai's Movement, Islamabad, National Institute of Historical and Cultural Research, 2015.

Spain, J. W. The Way of the Pathans, Karachi, Oxford University Press, 1972.

Steul, W. Paschtunwali: Ein Ehrenkodex und seine rechtliche Relevanz, Wiesbaden, Steiner, 1981.

Wieland-Karimi, A. Islamische Mystik in Afghanistan: Die strukturelle Einbindung der Sufik in die Gesellschaft, Stuttgart, Steiner, 1998. 